\title{
Outcomes of Different Methods for Analysis of Biliary Brush Cytology and of Factors Associated with Positive Diagnosis in an Age-Dependent Retrospective Review
}

\author{
Mariana Costa ${ }^{a} \quad$ Jorge Canena ${ }^{a, d} \quad$ Luís Mascarenhas-Lemos $^{b}$ Rafaela Loureiro ${ }^{a}$ \\ Mário Silva ${ }^{a}$ Diana Carvalho ${ }^{a}$ Tiago Capela ${ }^{a}$ Pedro Russo ${ }^{a}$ Gonçalo Ramos $^{a}$ \\ António Mateus-Dias ${ }^{a}$ Mário Ferraz-Oliveirab Pedro Mota Veigac \\ João Coimbra a \\ ${ }^{a}$ Department of Gastroenterology, Santo António dos Capuchos Hospital do Centro Hospitalar Lisboa Central,

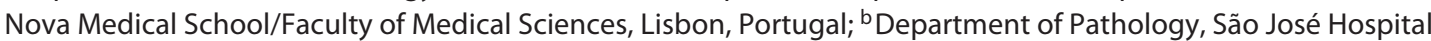 \\ do Centro Hospitalar Lisboa Central, Lisbon, Portugal; ' ${ }^{C}$ Curva de Gauss - Research, Training and Consulting,

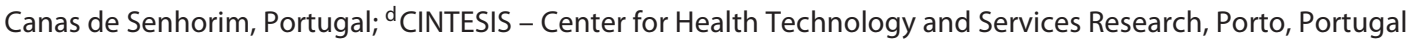

Keywords

Biliary cytology $\cdot$ Age $\cdot$ ERCP $\cdot$ Predictors of outcome

\section{Abstract}

Background and Aims: Brush cytology during endoscopic retrograde cholangiopancreatography $(E R C P)$ is the most frequently used strategy for obtaining a tissue sample from an indeterminate biliary stricture. A recent study reported that age is a factor associated with positive yields, but further analysis of how age influences the results was lacking. We aimed to evaluate clinical effectiveness of biliary cytology and prognostic factors for a positive outcome, especially age. Methods: This study was a single-center, retrospective, clinical study of 77 consecutive patients who underwent brush cytology during ERCP to obtain a diagnosis of an indeterminate biliary stricture. We compared 2 routine cytology techniques: A (smear); B (centrifugation of the cytological material collected and the cut-off brush + cell block when suffi-

Mariana Costa and Jorge Canena contributed equally to this article.

\section{KARGER}

E-Mail karger@karger.com www.karger.com/pjg (c) 2018 Sociedade Portuguesa de Gastrenterologia Published by S. Karger AG, Basel

Karger

Open access

This article is licensed under the Creative Commons AttributionNonCommercial-NoDerivatives 4.0 International License (CC BY NC-ND) (http://www.karger.com/Services/OpenAccessLicense) Usage and distribution for commercial purposes as well as any distribution of modified material requires written permission. cient amount of material was available). The data were collected aiming to compare the accuracy of the different techniques used and the prognostic factors affecting the outcome, with a particular focus on age. The yield for brush cytology was compared with the gold standard defined as either definitive histology or the long-term clinical course. $\boldsymbol{R e}$ sults: The overall accuracy of the 2 used methods was $75.3 \%$. Sensitivity was $52.5 \%$, specificity was $100 \%$, positive predictive value was $100 \%$, and negative predictive value was $66.1 \%$. Although not statistically significant, there was a trend toward accuracy for method B compared with method A (80.4 vs. $65.4 \% ; p=0.153$ ). Multiple logistic regression analysis showed that younger age was the only independent prognostic factor associated with a positive diagnosis (OR 0.95; $95 \% \mathrm{Cl} 0.90-0.99 ; p=0.039$ ). Receiver operating characteristic curves for age yielded an area under the curve value of $68.2 \%$. On the basis of the Youden index, 69 years was found to be the optimal cutoff for age. Conclusions: In this series, the accuracy of routine biliary brush cytology was not equal for all methods and ages; in particular, younger patients (below 69 years) tended to have a higher probability of a correct diagnosis.

(C) 2018 Sociedade Portuguesa de Gastrenterologia Published by S. Karger AG, Basel 
Eficácia de Diferentes Métodos de Avaliação da Citologia Biliar e dos Factores Associados a um Diagnóstico Positivo após Análise Retrospectiva Focada na Idade

\section{Palavras Chave}

Citologia biliar · Idade · CPRE · Fatores preditivos

\section{Resumo}

Introdução: a citologia biliar é a técnica mais utilizada durante a CPRE para o diagnóstico de uma estenose indeterminada. Um artigo recente refere a importância da idade como fator preditivo de um resultado positivo, embora sem analisar este dado. Pretendemos avaliar a acuidade da citologia biliar e dos factores associados para a obtenção de um resultado positivo com especial interesse na idade. Métodos: análise retrospectiva de um único centro de 77 doentes consecutivos submetidos, durante CPRE a citologia biliar para esclarecer a etiologia de uma estenose biliar. A análise comparou 2 técnicas de rotina: $A$ (esfregaço); B (centrifugação do material colectado e da escova+cell block quando existia material suficiente). Pretendeu-se comparar a acuidade diagnóstica dos 2 diferentes métodos e dos factores de prognóstico associados ao resultado em especial a idade. A acuidade da citologia foi comparada com o "gold standard" definido como a histologia definitiva ou o curso clínico a longo prazo. Resultados: a acuidade global dos diferentes métodos foi 75.3\%. A sensibilidade foi $52.5 \%$, a especificidade foi $100 \%$, VPP foi $100 \%$ e o VPN foi $66.1 \%$. Apesar de não ser estatisticamente definitivo existiu maior acuidade do método $\mathrm{B}$, em comparação com o A ( 80.4 vs. $65.4 \% ; p=0.153$ ). $A$ análise multivariada por regressão logística mostrou que a menor idade é o único fator de prognóstico independente associado a um resultado positivo (OR: 0.95; $95 \% \mathrm{Cl}: 0.90-0.99 ; p=0.039$ ). As curvas ROC para a idade apresentaram um valor para a AUC de $68.2 \%$. O índice de Youden, determinou que os 69 anos seriam o "cutoff" ideal para a idade. Conclusões: nesta população a acuidade de citologia biliar não foi idêntica para todos os métodos e idades; em particular doentes com idade inferior a 69 anos apresentam maior probabilidade de obter um diagnóstico correto.

(c) 2018 Sociedade Portuguesa de Gastrenterologia Publicado por S. Karger AG, Basel

\section{Introduction}

Bile duct strictures can occur with different etiologies, such as inflammatory conditions of the pancreas, ampulla, gallbladder, and biliary tree, cancers involving the periampullary region, or even metastatic disease from malignancy located elsewhere in the body $[1,2]$. Accurately diagnosing the strictures is essential to initiate adequate therapy without further delay and to avoid further invasive examinations. Obtaining a tissue diagnosis appears to be a key factor. In recent years, several techniques have emerged for obtaining an adequate cellular specimen from the stricture, such as forceps biopsy during cholangioscopy [3-6] or endoscopic ultrasonography-guided fine needle aspiration/biopsy [79]. However, the most commonly used strategy to obtain a tissue sample of the stricture is brush cytology during endoscopic retrograde cholangiopancreatography (ERCP). Brush cytology is a technique with a low complication rate, widespread availability, relative ease of performance, and the ability to sample nearly the entire biliary tree [1, 10-22]. However, the diagnostic accuracy of the technique is relatively low, ranging from 5.9 to $65 \%[1,10-22]$. In a recent review of the literature from 2002 until 2012, including 16 studies and 1,556 patients, biliary brushing cytology was found to be associated with an overall sensitivity of $41.6 \%$ and a negative predictive value (NPV) of 58\% [23]. To further increase the accuracy of brush cytology, many reports have described different techniques to improve positive yields, including stricture dilatation, repeat brushing, grasp and basket cytology, modified cytology brushes, the cell block method, digital image analysis, and fluorescence in situ hybridization (FISH) [24-31]. These methods all have different success rates, but most of them have increased costs. Several studies have compared routine cytology with more advanced and complex diagnostic methods, but few studies have compared different routine cytology techniques to obtain a positive diagnostic yield. Further, in a recent study analyzing the factors that affect the accuracy of brush cytology, age emerged as a factor associated with positive yields, but there was no further analysis of how age influenced the results [1]. Therefore, we conducted a retrospective study to compare the accuracy of different techniques used for routine cytology and the prognostic factors that affect the accuracy of biliary brush cytology, with a special focus on age as a factor associated with a positive result. 


\section{Methods}

\section{Patients and Setting}

This was a single-center, retrospective, clinical study with a single-arm design. Interventional endoscopy database records from our academic institution were retrospectively reviewed to identify all consecutive patients who underwent ERCP procedures, including biliary brush cytology for suspected malignant biliary stricture, between July 2009 and December 2014. The following criteria were used for inclusion in this study: (1) suspicion of malignant biliary obstruction without prior histopathological confirmation; (2) definitive cytological diagnosis, namely, benign or malignant cytology in all cases; and (3) a definitive final benign or malignant diagnosis. The final diagnosis was achieved by histological confirmation obtained by other methods (endoscopic ultrasound-guided fine needle aspiration, endoscopic biopsy or surgical resection) or by clinical outcome. The latter was determined on the basis of the absence of clinical or imaging features of malignancy during a minimum follow-up of 1 year.

The data were collected from various sources, including imaging and endoscopic reports, patient charts (manual and electronic), clinical notes, our prospective database, and follow-up clinic visits. The collected data included patient demographics, the anatomical location of the stricture, the results of the cytological brushing and associated methods, the definitive diagnosis, the type and location of the malignant tumor, and the follow-up time. This study was conducted at a single academic institution, and all patients provided informed written consent before their procedures. The Ethics Committee at our institution approved this retrospective review.

\section{Technique and Follow-Up}

The ERCP procedures used to obtain cytological specimens were similar in all cases. After accessing the bile duct and placing a guidewire across the stricture under fluoroscopic guidance, a double lumen wire-guided cytology brush (Boston Scientific, Natick, MA, USA; Cook Medical, Winston-Salem, NC, USA) was advanced into the stricture. The cytological samples were obtained by several passes (at least 10) of the brush across the stricture. During the study, 3 different techniques were used to assess the cytology results.

- Technique 1. Between July 2009 and July 2012, the collected cytological material was immediately transferred to glass slides by an endoscopy team member, who smeared the cellular material directly from the brush. The smears were air dried and sent to the laboratory, where routine preparations were conducted according to the May-Grünwald-Giemsa method.

- Technique 2. From August 2012 to the current date, the collected cytological material and the cut-off brush head were placed into a $10 \%$ buffered formalin solution for preservation. All material was centrifuged in $45 \mathrm{~mL}$ disposable centrifuge tubes at 2,800 rpm for $5 \mathrm{~min}$ to create cell pellets and direct or cytocentrifuged (1,500 rpm for $5 \mathrm{~min}$ ) smears that were prepared and stained with the Papanicolaou method.

- Technique 3. When there was a sufficient amount of material, cell agar blocks were prepared, and paraffin slides were obtained through routine histologic methods and stained with hematoxylin-eosin (cell block).
Thus, until July 2012, only technique 1 was used. After August 2012 , technique 1 was used in combination with technique 2 or in combination with techniques 2 and 3. Therefore, in our study, patients were divided into 2 groups: group A included patients submitted to technique 1 (smear only); group B included patients submitted to techniques $1+2+3$ (smears + centrifugation of collected material) and cell block when sufficient material was available. The samples were classified into 5 categories as described elsewhere: (1) negative for malignancy; (2) atypical, considered reactive; (3) suspicious for malignancy; (4) malignant; or (5) unsatisfactory, if fewer than 5 clusters with $\geq 10$ well-preserved cells per cluster on $\geq 2$ slides were present. In this study, samples that were definitively positive for malignant biliary brush cytology were defined as category 3 or 4 .

Follow-up continued from the initial ERCP in which cytological specimens were obtained until the death of the patient or at least after 1 year from the cytological diagnosis. Only patients with complete follow-up were included in the study. Follow-up was obtained by review of the clinical notes provided by regular clinic visits or by medical assistant reports, imaging, lab results, data in our prospective database, and structured telephone interviews with medical assistants or family during follow-up or at the time of manuscript preparation.

\section{Endpoints and Definitions}

The primary endpoint was to access the accuracy of 2 different methods in obtaining a cytological diagnosis. Secondary endpoints included the determination of factors associated with positive yields and their ability to discriminate between positive and negative results, globally and for each method, sensitivity, specificity, positive predictive value (PPV), NPV, and complications of the technique. Complications were defined as any adverse event related to the ERCP or brush cytology and were carefully monitored according to previously determined definitions. Compressive lesions were defined as lesions with a mass effect located outside the biliary tree (e.g., pancreatic adenocarcinoma, metastasis).

\section{Statistical Analyses}

The intention-to-treat method was used for all analyses. Qualitative variables were described in terms of frequency distribution. Quantitative variables were described by mean, standard deviation, median, and range. Factors associated with positive yields were assessed using univariate analysis followed by multiple logistic regression analysis, as appropriate. Positive factors resulting from multivariate analysis were tested for their ability to discriminate between positive and negative results with receiver operating characteristic (ROC) curves. The overall performance of the ROC curve analysis was quantified by computing the area under the curve and 95\% confidence intervals (CI). The optimal cutoffs of the ROC curve analysis were assessed using the Youden index. The univariate analysis was conducted using the $\chi^{2}$ test and the Fisher exact test for categorical variables and the Mann-Whitney $U$ test and the Student $t$ test for continuous variables. Sensitivity, specificity, PPV, NPV, and diagnostic accuracy were calculated for global cytological brushing and for each sampling method. The 95\% CI for the latter was calculated with the Wilson method. All reported $p$ values are for 2 -tailed tests, and $p<0.05$ was considered to be statistically significant. All statistical analyses were performed using the SPSS software package, version 23 (Statistical Package for the Social Sciences, IBM Corporation, Armonk, NY, USA). 
Table 1. Patients' demographics and final diagnosis

\begin{tabular}{|c|c|}
\hline \multicolumn{2}{|l|}{ Gender } \\
\hline Male & $36(46.8)$ \\
\hline Female & $41(53.2)$ \\
\hline Mean age \pm SD (range), years & $68.3 \pm 14.3(14-96)$ \\
\hline \multicolumn{2}{|l|}{ Type of lesion } \\
\hline Malignant ampulla & $1(1.3)$ \\
\hline Cholangiocarcinoma & $20(26.0)$ \\
\hline Pancreatic cancer & $29(37.7)$ \\
\hline Metastasis & $5(6.5)$ \\
\hline Chronic cholecystitis & $3(3.9)$ \\
\hline Chronic pancreatitis & $6(7.8)$ \\
\hline Idiopathic & $12(15.5)$ \\
\hline IgG4 cholangitis & $1(1.3)$ \\
\hline \multicolumn{2}{|l|}{ Result of the cytology } \\
\hline Benign & $40(51.9)$ \\
\hline Malignant & $37(48.1)$ \\
\hline \multicolumn{2}{|l|}{ Final result } \\
\hline Correct & $59(79.6)$ \\
\hline Wrong & $18(23.4)$ \\
\hline \multicolumn{2}{|l|}{ Method } \\
\hline $\mathrm{A}$ & $26(33.8)$ \\
\hline $\mathrm{B}$ & $51(66.2)$ \\
\hline \multicolumn{2}{|l|}{ Lesion location } \\
\hline Intrahepatic & $4(5.2)$ \\
\hline Extrahepatic & $73(94.8)$ \\
\hline \multicolumn{2}{|l|}{ Gross appearance } \\
\hline Compressive & $45(58.4)$ \\
\hline Noncompressive & $32(41.6)$ \\
\hline
\end{tabular}

Values are $n(\%)$ unless otherwise indicated. SD, standard deviation.

Results

\section{Patient Demographics and Final Diagnosis}

In total, 77 patients (36 males and 41 females) with a median age of 71 years (range 14-96 years) and with a cytological diagnosis of either benign or malignant stricture were included in the study. Of the 77 patients, 40 patients had a cytological diagnosis of benign stricture, which at the end of the study was proved to be incorrect in 18 patients $(18 / 40)$, which had a malignant condition. Of the 77 patients, 37 had a cytological diagnosis of malignant stricture, which at the end of the study was proven to be correct for all patients (37/37). Therefore, at the end of the study, 59 (59/77, 79.6\%) diagnoses made by cytology were correct and 18 cytological diagnostics (18/77, 23.4\%) were wrong. A definitive malignant diagnosis was made in $18+37=55$ patients $(71.4 \%)$, including 29 patients with pancreatic adenocarcinomas $(29 / 55$,
52.8\%), 20 patients with cholangiocarcinomas (CCAs) $(20 / 55,36.4 \%), 5$ patients with metastatic disease and biliary compression $(5 / 55,8.9 \%)$, and 1 patient with ampullary tumor $(1 / 55,1.9 \%)$.

Thirteen patients had an initial brush cytology considered unsatisfactory, meaning the sample obtained was not sufficient to provide a final diagnosis of benign or malignant; therefore, these patients underwent another ERCP to obtain a sample in which a definitive cytological diagnosis (benign or malignant) was made by the pathologist. Of the 13 patients which were submitted to another ERCP, 6 obtained a malignant diagnosis that was proven to be correct in all patients, and 7 obtained a benign diagnosis which was proven to be correct in 5 patients. The repetition of the ERCP for obtaining a cytological diagnosis is not a routine procedure and is performed only when the final diagnosis is unclear or when for oncological reasons there is a clear need of a malignancy cytologi$\mathrm{cal} /$ histological report. At the end of the study, 22 patients had a benign diagnosis and remained alive, with a mean follow-up of 27.7 months (range 12-55.9 months). The remaining 55 patients were dead at the end of the study. Of the 55 patients with a malignant definitive diagnosis, $40 / 55$ patients had a histological diagnosis obtained as follows: (a) by endoscopic ultrasound in 26 patients with either pancreatic cancer or retroperitoneal metastasis; (b) by endoscopic biopsies obtained from 6 patients ( 5 pancreatic cancer, 1 neoplasm of the ampulla); and (c) during surgery ( 3 pancreatic cancer, 5 CCAs). The remaining 15 malignant diagnoses were made by imaging and clinical outcome. Further data concerning these observations are summarized in Table 1.

\section{Accuracy, Sensitivity, Specificity, PPV, and NPV}

Of the 77 patients included in the study, 26 patients $(33.8 \%)$ were in group A, and 51 patients $(66.2 \%)$ were in group B (Table 2). Overall, the accuracy of biliary brush cytology was 75.3\% (95\% CI 64.6-83.6\%). The diagnostic sensitivity was $52.5 \%$ (95\% CI $37.5-67.1 \%$ ), the specificity was $100 \%$ (95\% CI $90.6-100 \%)$, the PPV was $100 \%$ (95\% CI 84.5-100\%), and the NPV was 66.1\% (95\% CI 53-77.1\%). Although it was not statistically significant, there was a trend toward accuracy for method B compared with method A (80.4 vs. $65.4 \%$; $p=0.153$ ).

\section{Univariate and Multivariate Analysis of Prognostic \\ Factors Associated with a Positive Diagnosis}

The univariate analysis of prognostic factors associated with the accuracy of biliary brush cytology is shown in Table 3. In the univariate analysis, we evaluated 5 vari- 
Table 2. Overall and individual diagnostic accuracy, sensitivity, PPV, and NPV for 3 routine cytology techniques

\begin{tabular}{llllll}
\hline Method & $\begin{array}{l}\text { Accuracy, } \% \\
(95 \% \mathrm{CI})\end{array}$ & $\begin{array}{l}\text { Sensitivity, \% } \\
(95 \% \mathrm{CI})\end{array}$ & $\begin{array}{l}\text { Specificity, \% } \\
(95 \% \mathrm{CI})\end{array}$ & $\begin{array}{l}\text { PPV, \% } \\
(95 \% \mathrm{CI})\end{array}$ & $\begin{array}{l}\text { NPV, \% } \\
(95 \% \mathrm{CI})\end{array}$ \\
\hline A & $65.4(46.2-80.6)$ & $40.0(37.5-67.1)$ & $100(74.1-100)$ & $100(61.0-100)$ & $55.0(34.2-74.2)$ \\
B & $80.4(67.5-89.0)$ & $60.0(40.7-76.6)$ & $100(87.1-100)$ & $100(79.6-100)$ & $72.2(56.0-84.2)$ \\
Total & $75.3(64.6-83.6)$ & $52.5(37.5-67.1)$ & $100(90.6-100)$ & $100(84.5-100)$ & $66.1(53-77.1)$ \\
\hline
\end{tabular}

A, smear; B, centrifugation of the cytological material collected and the cut-off brush + cell block when possible; PPV, positive predictive value; $\mathrm{PNV}$, negative predictive value; $\mathrm{CI}$, confidence interval.

Table 3. The univariate analysis of prognostic factors associated with the accuracy of biliary brush cytology

\begin{tabular}{|c|c|c|c|}
\hline & \multicolumn{2}{|c|}{ Final outcome } & \multirow[t]{2}{*}{$p$} \\
\hline & wrong & correct & \\
\hline \multicolumn{3}{|l|}{ Sex } & 0.445 \\
\hline Female & $11(26.8)$ & $30(73.2)$ & \\
\hline Male & $7(19.4)$ & $29(80.6)$ & \\
\hline Mean age $\pm S D$, years & $74.7 \pm 13.2$ & $66.3 \pm 14.1$ & $0.029 *$ \\
\hline \multicolumn{3}{|l|}{ Type of lesion } & 0.103 \\
\hline Ampulla & $1(100)$ & $0(0)$ & \\
\hline Cholangiocarcinoma & $6(30)$ & $14(70)$ & \\
\hline Pancreatic cancer & $9(31)$ & $20(69)$ & \\
\hline Metastasis & $2(33.3)$ & $4(66.7)$ & \\
\hline Chronic cholecystitis & $0(0)$ & $3(100)$ & \\
\hline Chronic pancreatitis & $0(0)$ & $6(100)$ & \\
\hline Idiopathic & $0(0)$ & $11(100)$ & \\
\hline IgG4 cholangitis & $0(0)$ & $1(100)$ & \\
\hline \multicolumn{3}{|l|}{ Gross appearance } & 0.793 \\
\hline Compressive & $11(24.4)$ & $34(75.6)$ & \\
\hline Noncompressive & 7 (21.9) & $25(78.1)$ & \\
\hline \multicolumn{3}{|l|}{ Lesion location } & 0.231 \\
\hline Intrahepatic & $2(50)$ & $2(50)$ & \\
\hline Extrahepatic & $16(21.9)$ & $57(78.1)$ & \\
\hline \multicolumn{4}{|l|}{ Method } \\
\hline A & $9(34.6)$ & $17(65.4)$ & 0.153 \\
\hline $\mathrm{B}$ & $9(17.3)$ & $42(82.7)$ & \\
\hline
\end{tabular}

Values are $n(\%)$ unless otherwise indicated. SD, standard deviation. * Statistically significant.

ables as follows: sex, age, the location of the biliary lesion (intrahepatic or extrahepatic), type of tumor, and gross appearance (compressive vs. noncompressive). Only age proved to be a statistically significant predictor of a positive diagnosis $(p=0.029)$. Multiple logistic regression analysis (Table 4 ) showed that younger age was the only independent prognostic factor associated with a positive
Table 4. Results of a multivariate logistic model to evaluate independent prognostic factors associated with a positive diagnosis

\begin{tabular}{lll}
\hline & OR $(95 \%$ CI $)$ & $p$ \\
\hline Sex & $0.72(0.26-1.95)$ & 0.515 \\
Age & $0.95(0.90-0.99)$ & $0.039^{*}$ \\
Gross appearance & & \\
$\quad$ Compressive & $0.90(0.332 .45)$ & 0.840 \\
Method B & $1.60(0.544 .73)$ & 0.355 \\
\hline \multicolumn{2}{c}{ OR, odds ratio; CI, confidence interval. ${ }^{*}$ Statistically significant. } \\
\hline
\end{tabular}

biliary brush cytology diagnosis (OR 0.95; 95\% CI 0.90$0.99 ; p=0.039$ ). This finding suggests that the older the patient, the lower the probability of obtaining a correct diagnosis when using this method.

\section{Analysis of ROC Curves for Age}

ROC curve analysis (Fig. 1) yielded an area under the curve value of $68.2 \%$ (95\% CI 53.7-82.8\%; $p=0.02$ ) for age as a discriminator of accuracy for biliary brush cytology. On the basis of the Youden index, 69 years was found to be the optimal cutoff for age. Using this optimal cutoff, the accuracy of the test for patients younger than 69 years was significantly increased $(p=0.02)$ from $63.6 \%$ (95\% CI $48.9-76.2 \%)$ to $90.9 \%$ (95\% CI 76.4-96.9\%) compared with patients $>69$ years (Table 5).

\section{Discussion}

According to the findings of this single-center, retrospective, clinical study with a single-arm design, the accuracy of 3 different routine biliary brush cytology techniques in obtaining a positive diagnostic yield was $75.3 \%$ 
Table 5. Overall improvement of diagnostic accuracy, sensitivity, PPV, and NPV for the 3 cytology techniques using the optimal cutoff of 69 years, provided by the Youden index

\begin{tabular}{lllllr}
\hline Age & $\begin{array}{l}\text { Accuracy, } \% \\
(95 \% \mathrm{CI})\end{array}$ & $\begin{array}{l}\text { Sensitivity, \% } \\
(95 \% \mathrm{CI})\end{array}$ & $\begin{array}{l}\text { Specificity, \% } \\
(95 \% \mathrm{CI})\end{array}$ & $\begin{array}{l}\text { PPV, \% } \\
(95 \% \mathrm{CI})\end{array}$ & $\begin{array}{l}\text { NPV, \% } \\
(95 \% \mathrm{CI})\end{array}$ \\
\hline$>69$ years & $\begin{array}{l}63.6(76.2-80.6) \\
<69 \text { years }\end{array}$ & $23.8(10.6-45.1)$ & $100(85.7-100)$ & $100(56.6-100)$ & $59(43.4-72.9)$ \\
\hline
\end{tabular}

PPV, positive predictive value; PNV, negative predictive value; $\mathrm{CI}$, confidence interval.

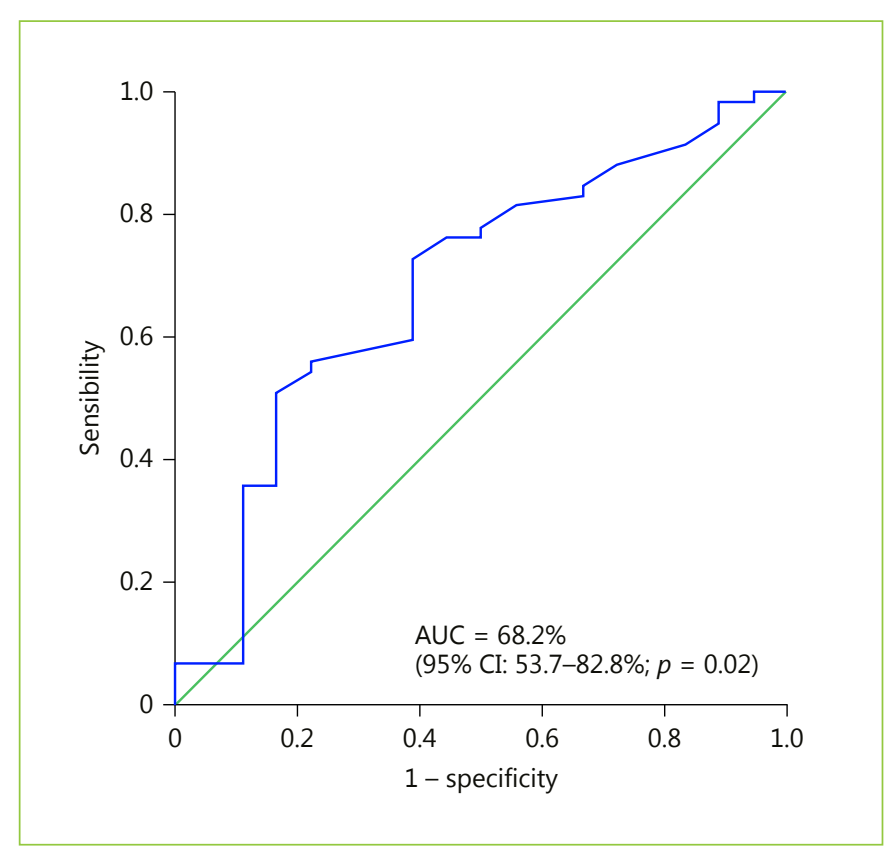

Fig. 1. Receiver operating characteristic curve for age, discriminating between patients with a correct and a wrong diagnosis.

(95\% CI 64.6-83.6\%), and the sensitivity was 52.5\% (95\% CI 37.5-67.1\%). Although not statistically significant, patients in group B (centrifugation of the cytological material collected and the cut-off brush + cell block when possible) showed better accuracy and better sensitivity than method A (cytological material collected and transferred to a glass slide). Younger age was a significant predictor of a positive diagnosis and was the only independent factor associated with a positive yield. ROC curve analysis indicated that patients younger than 69 years had a higher probability of obtaining a correct diagnosis through this method.

Bile duct strictures are relatively typical findings on ERCP. Obtaining a tissue diagnosis of these strictures is valuable not only for treatment planning but also for avoiding additional invasive and costly procedures. Although biliary brush cytology is the most widely used tissue sampling technique, it has been associated with modest sensitivity in a large number of studies $[3,18,21]$. The current literature indicates a diagnostic sensitivity for cancer detection ranging from 6 to $65 \%[1,10-22]$. In a 10 -year review of the literature, Burnett et al. [21] identified 16 studies (involving a total of 1,556 patients). In these studies, after combining data, the authors obtained an overall sensitivity of $41.6 \%$ and a NPV of $58.0 \%$. Several studies have reported poor results, such as $5.9 \%$ in a study by Draganov et al. [3] and $18 \%$ in a study by Harewood et al. [18]. In contrast, higher sensitivities were reported by Urbano et al. [19], Arvanitakis et al. [20], and Temiño López-Jurado et al. [10] $(65,63$, and 61\%, respectively). Several factors have been highlighted to explain this large variability in sensitivity, such as the endoscopic technique, type of brush, use of dilatation and basket, cytological techniques, and cytological criteria for malignancy, interpathologist variation for biliary cytology interpretation, patient age, and the type, localization, and length of the tumor $[1,10,13,15,18,21,22,24]$. In the current study, we found an overall sensitivity of $52.5 \%$, a result in line with the previous literature. However, there is a potential unrecognized source of variability in the results concerning the cytological technique. In our study, a dedicated technique (method B) of cutting the brush and centrifuging the collected material, compared with a smear into a glass slide (method A), increased overall sensitivity; this result has not been clearly observed in previous reports. Therefore, this is a novel insight which has not been explored in previous literature. Accordingly, to our staff of pathology, the centrifugation of the brush has the potential of increasing the number of cells to be analyzed in the new smear and, therefore, increasing the yield of the technique. Furthermore, the creation of a cell block complementing method B also increased the sensitivity of
10

GE Port J Gastroenterol 2019;26:5-13 DOI: $10.1159 / 000487153$
Costa et al. 
cytodiagnosis. The usefulness of a cell block has been clearly shown in the literature. Several studies have reported that using a cell block can improve the sensitivity in the diagnosis of malignancies and is a strategy that should be included in the diagnostic analysis $[29,32]$.

Few studies have previously analyzed the factors associated with positive results in detail. McGuire et al. [33], in 1996, first reported a higher yield of positive results obtained through the use of brush cytology in strictures of the body and head of the pancreas, compared with malignant strictures from cancers located at the pancreas genu, tail, and biliary ampulla. In a recent report from Japan, Nishikawa et al. [6] compared 3 different sampling methods for the diagnosis of bile duct cancer and found that the accuracy of brushing cytology was significantly higher for nonflat (periductal infiltrating) lesions. Mahmoudi et al. [1] reviewed 189 patients and reported that the variables associated with positive cytology brushing included mass size $>1 \mathrm{~cm}$, length of stricture $>1 \mathrm{~cm}$, and age. In this study, age was not further analyzed. However, in the current study, younger age was found to be an independent prognostic factor. The sensitivity of biliary brush cytology for patients younger than 69 years was $84.2 \%$. This is the first detailed analysis of age and the first report on this subject. We further recommend that future prospective studies analyze this subject to validate it further.

Different brush cytology strategies have been used to accurately identify neoplasms. For example, the use of a second brushing is associated with a higher diagnostic yield [34]. However, this observation has not been consistently shown in the literature [1]. Several studies have suggested that the increased exfoliation of tumor cells due to stricture manipulation may increase the diagnostic yield of biliary brush cytology [23-25, 28]. Farrell et al. [28] found that stricture dilatation to 10 French and endoscopic needle aspiration significantly increased both the sensitivity and specificity of biliary brushing cytology. However, such findings have not consistently been demonstrated in the literature, and several authors have reported that stricture dilatation before brush cytology does not increase the sensibility of the technique, although the reasons for that discrepancy remain unknown [1, 34]. Compared with conventional brush cytology, the use of a dedicated basket has been associated with increased sensitivity for cancer detection in a randomized trial [23]. However, in a recent study, biliary sampling with a conventional Dormia basket was found to be comparable to conventional brush cytology in detecting malignant bile duct stricture [24]. For that reason, the use of a basket

Biliary Brush Cytology and Age should be considered with caution until further studies are available. A modified cytology brush can eventually increase the diagnostic yield of the technique. Shieh et al. [25] reported that the use of a newly designed ERCP brush is able to double the diagnostic yield of brush cytology. However, these findings have not yet been replicated, and they should be interpreted with caution until more studies have been undertaken.

New molecular markers, such as digital image analysis (DIA) and FISH, have emerged and may improve diagnostic sensitivity for patients with indeterminate biliary strictures [26, 27, 29]. In 1 study, Levy et al. [27] reported that DIA, FISH, and composite DIA/FISH significantly improved the diagnostic yield for patients with surgically proven malignancy and negative cytology and histology.

Over the past 10 years, the development of a singleoperator peroral cholangioscope in which a dedicated mini-forceps biopsy can be used to obtain target cholangioscopy biopsy specimens has increased the diagnostic accuracy of indeterminate biliary lesions [3-6]. A recent systematic review of 10 studies involving 456 patients reported a pooled sensitivity and specificity of cholangioscopy-guided biopsies in the diagnosis of malignant biliary strictures of 60.1 and $98.0 \%$, respectively [4]. In this systematic review, 6 studies were included that specifically reported the role of cholangioscopy target biopsies in CCA. In the subgroup analysis of patients with CCA, the pooled sensitivity and specificity to detect CCA were 66.2 and $97.0 \%$, respectively. However, in a provocative paper, Nishikawa et al. [6] compared the diagnostic accuracy of peroral cholangioscopy visual findings and cholangioscopy-guided biopsies for indeterminate strictures. They reported a sensitivity, specificity, and accuracy of 100, 91.7, and $97.0 \%$, respectively, for peroral video-cholangioscopic visual findings and of $38.1,100$, and $60.6 \%$, respectively, for cholangioscopy-guided forceps biopsy findings. A significant difference has been observed regarding accuracy $(p=0.0018)$. Another recent technique has been reported to further increase the sensitivity of cholangioscopy impression and tissue sampling, namely adding probe-based confocal laser endomicroscopy (pCLE) to the diagnostic workup $[31,35,36]$. However, the initial results were not replicated in a recent paper [37], and, therefore, the value of pCLE should be considered with caution, before it is recommended for routine practice. Another interesting finding that has emerged from these studies is that cytology should always be the first diagnostic procedure.

In the current study, younger patients (below 69 years) tended to have a higher probability of a correct diagnosis. 
This is a novel observation which has not been reported before. In the study of Mahmoudi et al. [1], age was also a factor associated with a positive yield. However, in the above-mentioned study, the authors reported that patients with older age had a higher probability of obtaining a correct cytological diagnosis. Age is a continuous variable and, therefore, in the study of Mahmoudi et al. [1] the authors did not dichotomize this variable. However, in the current study, age was further analyzed with ROC curve analysis and the Youden index, and, surprisingly, younger patients (below 69 years) are associated with a positive diagnosis, and there is no clear explanation for this observation. We can speculate that in younger patients, in a general manner, malignancies tend to be more aggressive and, therefore, have higher cellularity which facilitates the brush diagnosis. Perhaps, in the near future, we shall gain new insights into this observation.

The current study has several limitations that should be considered. First, this was a retrospective study, and, hence, the number of included patients was limited because some of the identified consecutive patients had incomplete data and were excluded from the analysis. Our data may thus have been subject to selection bias. Another limitation was the subject of the study, which is not new and has been extensively debated. Another potential weakness is the limited number of patients, thus limiting the statistical strength of the study, particularly the comparison between cytological methods. The strengths of our study are the comparison of the accuracy of different techniques used in routine cytology, which was not available in previous studies, and the extensive analysis of prognostic factors affecting the accuracy of biliary brush cytology. To the best of our knowledge, this is the first study to analyze age in detail as a prognostic factor for routine biliary brush cytology. In conclusion, in this series, the accuracy of routine biliary brush cytology was not equal for all methods, and younger age was associated with a higher likelihood of a correct diagnosis.

\section{Statement of Ethics}

All patients provided informed written consent before their procedures. The Ethics Committee at our institution approved this retrospective review.

\section{Disclosure Statement}

Jorge Canena is a consultant for Boston Scientific but did not receive any financial arrangements for this research or any assistance with manuscript preparation. The remaining authors have no conflicts of interest to declare.

\section{References}

1 Mahmoudi N, Enns R, Amar J, AlAli J, Lam E, Telford J: Biliary brush cytology: factors associated with positive yields on biliary brush cytology. World J Gastroenterol 2008; 14 : 569-573.

2 Canena J, Coimbra J, Carvalho D, et al: Endoscopic bilio-duodenal bypass: outcomes of primary and revision efficacy of combined metallic stents in malignant duodenal and biliary obstruction. Dig Dis Sci 2014;59:2779-2789.

-3 Draganov P, Chauhan S, Wagh M, et al: Diagnostic accuracy of conventional and cholangioscopy-guided sampling of indeterminate biliary lesions at the time of ERCP: a prospective, long-term follow-up study. Gastrointest Endosc 2012;75:347-353.

4 Navaneethan U, Hasan MK, Lourdusamy V, Njei B, Varadarajulu S, Hawes RH: Single-operator cholangioscopy and targeted biopsies in the diagnosis of indeterminate biliary strictures: a systematic review. Gastrointest Endosc 2015;82:608-614.

-5 Woo YS, Lee JK, Oh SH, et al: Role of SpyGlass peroral cholangioscopy in the evaluation of indeterminate biliary lesions. Dig Dis Sci 2014;59:2565-2570.
6 Nishikawa T, Tsuyuguchi T, Sakai Y, Sugiyama H, Miyazaki M, Yokosuka O: Comparison of the diagnostic accuracy of peroral videocholangioscopic visual findings and cholangioscopy-guided forceps biopsy findings for indeterminate biliary lesions: a prospective study. Gastrointest Endosc 2013;77:219-226.

7 Khashab MA, Fockens P, Al-Haddad MA: Utility of EUS in patients with indeterminate biliary strictures and suspected extrahepatic cholangiocarcinoma (with videos). Gastrointest Endosc 2012;76:1024-1033.

$\checkmark 8$ Weilert F, Bhat YM, Binmoeller KF, et al: EUS-FNA is superior to ERCP-based tissue sampling in suspected malignant biliary obstruction: results of a prospective, singleblind, comparative study. Gastrointest Endosc 2014;80:97-104.

\9 De Moura DT, Moura EG, Bernardo WM, et al: Endoscopic retrograde cholangiopancreatography versus endoscopic ultrasound for tissue diagnosis of malignant biliary stricture: systematic review and meta-analysis. Endosc Ultrasound 2016, DOI: 10.4103/23039027.193597.
10 Temiño López-Jurado R, Cacho Acosta G, Argüelles Pintos M, et al: Diagnostic yield of brush cytology for biliary stenosis during ERCP. Rev Esp Enferm Dig 2009;101:385394.

-11 Shieh FK, Luong-Player A, Khara HS, et al: Improved endoscopic retrograde cholangiopancreatography brush increases diagnostic yield of malignant biliary strictures. World J Gastrointest Endosc 2014;6:312-317.

12 Navaneethan U, Njei B, Lourdusamy V, Konjeti R, Vargo JJ, Parsi MA: Comparative effectiveness of biliary brush cytology and intraductal biopsy for detection of malignant biliary strictures: a systematic review and meta-analysis. Gastrointest Endosc 2015;81: 168-176.

13 Sasaki Y, Okabe Y, Ishida Y, et al: Evaluation of endoscopic transpapillary brushing cytology for the diagnosis of bile duct cancer based on the histopathologic findings. Dig Dis Sci 2014;59:2314-2319.

14 Mohammad Alizadeh AH, Mousavi M, et al: Biliary brush cytology in the assessment of biliary strictures at a tertiary center in Iran. Asian Pac J Cancer Prev 2011;12:2793-2796. 
15 Nishikawa T, Tsuyuguchi T, Sakai Y, et al: Factors affecting the accuracy of endoscopic transpapillary sampling methods for bile duct cancer. Dig Endosc 2014;26:276-281.

16 Ponchon T, Gagnon P, Berger F, et al: Value of endobiliary brush cytology and biopsies for the diagnosis of malignant bile duct stenosis: results of a prospective study. Gastrointest Endosc 1995;42:565-572.

17 Pugliese V, Conlo M, Nicolo G, Saccomanno S, Gatteschi B: Endoscopic retrograde forceps biopsy and brush cytology of biliary strictures: a prospective study. Gastrointest Endosc 1995;42:520-526.

$>18$ Harewood GC, Baron TH, Stadheim LM, Kipp BR, Sebo TJ, Salomao DR: Prospective, blinded assessment of factors influencing the accuracy of biliary cytology interpretation. Am J Gastroenterol 2004;99:1464-1469.

- 19 Urbano M, Rosa A, Gomes D, Camacho E, Calhau CA, Leitão M: Team approach to ERCP-directed single-brush cytology for the diagnosis of malignancy. Rev Esp Enferm Dig 2008; 100:462-465.

20 Arvanitakis M, Hookey L, Tessier G, et al: Intraductal optical coherence tomography during endoscopic retrograde cholangiopancreatography for investigation of biliary strictures. Endoscopy 2009;41:696-701.

21 Burnett AS, Calvert TJ, Chokshi RJ: Sensitivity of endoscopic retrograde cholangiopancreatography standard cytology: 10-y review of the literature. J Surg Res 2013;184:304-311.

22 Mehmood S, Loya A, Yusuf MA: Biliary brush cytology revisited. Acta Cytol 2016;60:167172.
23 Dumonceau J, Macias Gomez C, Casco C, et al: Grasp or brush for biliary sampling at endoscopic retrograde cholangiography? A blinded randomized controlled trial. Am J Gastroenterol 2008;108:333-340.

24 Bang KB, Kim HJ, Park JH, et al: Comparison of brush and basket cytology in differential diagnosis of bile duct stricture at endoscopic retrograde cholangiopancreatography. Hepatobiliary Pancreat Dis Int 2014;13:622-627.

25 Shieh FK, Luong-Player A, Khara HS, et al: Improved endoscopic retrograde cholangiopancreatography brush increases diagnostic yield of malignant biliary strictures. World J Gastrointest Endosc 2014;6:312-317.

26 Salomao M, Gonda TA, Margolskee E, et al: Strategies for improving diagnostic accuracy of biliary strictures. Cancer Cytopathol 2015; 123:244-252.

27 Levy MJ, Baron TH, Clayton AC, et al: Prospective evaluation of advanced molecular markers and imaging techniques in patients with indeterminate bile duct strictures. Am J Gastroenterol 2008;103:1263-1273.

28 Farrell RJ, Jain AK, Brandwein SL, Wang H, Chuttani R, Pleskow DK: The combination of stricture dilation, endoscopic needle aspiration, and biliary brushings significantly improves diagnostic yield from malignant bile duct strictures. Gastrointest Endosc 2001;54: 587-594.

29 Boldorini R, Paganotti A, Andorno S, et al: A multistep cytological approach for patients with jaundice and biliary strictures of indeterminate origin. J Clin Pathol 2015;68:283-287.

30 De Bellis M, Fogel EL, Sherman S, et al: Influence of stricture dilation and repeat brushing on the cancer detection rate of brush cytology in the evaluation of malignant biliary obstruction. Gastrointest Endosc 2003;58:176-182.
1 Slivka A, Gan I, Jamidar P, et al: Validation of the diagnostic accuracy of probe-based confocal laser endomicroscopy for the characterization of indeterminate biliary strictures: results of a prospective multicenter international study. Gastrointest Endosc 2015;81: 282-290.

32 Nathan NA, Narayan E, Smith MM, Horn MJ: Cell block cytology. Improved preparation and its efficacy in diagnostic cytology. Am J Clin Pathol 2000;114:599-606.

33 McGuire DE, Venu RP, Brown RD, Etzkorn KP, Glaws WR, Abu-Hammour A: Brush cytology for pancreatic carcinoma: an analysis of factors influencing results. Gastrointest Endosc 1996;44:300-304.

-34 De Bellis M, Fogel EL, Sherman S, et al: Influence of stricture dilation and repeat brushing on the cancer detection rate of brush cytology in the evaluation of malignant biliary obstruction. Gastrointest Endosc 2003;58:176-182.

35 Meining A, Chen Y, Pleskow D, et al: Direct visualization of indeterminate pancreaticobiliary strictures with probe-based confocal laser endomicroscopy: a multicenter experience. Gastrointest Endosc 2011;74:961-968.

36 Baillie J: Distinguishing malignant from benign biliary strictures: can confocal laser endomicroscopy close the gap? Gastrointest Endosc 2015;81:291-293.

-37 Yang JF, Sharaiha RZ, Francis G, et al: Diagnostic accuracy of directed cholangioscopic biopsies and confocal laser endomicroscopy in cytology-negative indeterminate bile duct stricture: a multicenter comparison trial. $\mathrm{Mi}-$ nerva Gastroenterol Dietol 2016;62:227-233. 